\title{
Gender Diversity on Boards: A Cause for Multilateral Organizations
}

\author{
Marie-Anne Birken and Gian Piero Cigna*
}

\begin{abstract}
Good corporate decision-making requires the ability to consider and analyze issues from different perspectives. In the past, corporate governance literature has focused on ensuring that boards can draw on the diversity of their members' expertise and professional experience. Over the past few years, attention has increasingly shifted to the impact that gender diversity can bring to the decision-making process. There is now evidence to support the idea that gender-balanced boards boost the performance of companies and that companies with greater female representation on their boards are less likely to be affected by governance scandals involving bribery, fraud and other negative factors likely to depress business confidence.

In Europe, the discussion about gender diversity on boards is well advanced and a number of countries are aiming for ambitious targets. In the United States (US) the trend seems to have stalled, while in Asia it has not yet taken off, with only a few countries actively promoting gender diversity on boards.

This chapter considers the legislation and data on gender diversity on the boards of companies in Europe, the US and Asia. It critically reviews some of the measures introduced by companies, governments and institutional investors to address the gender diversity gap. It concludes by proposing concrete measures that governments, companies and investors may consider adopting to address the gender gap on boards. These measures may be appropriate for international financial institutions to pursue.
\end{abstract}

* Marie-Anne Birken (birkenm@ebrd.com) is General Counsel at the European Bank for Reconstruction and Development (EBRD) and Gian Piero Cigna (cignag@ebrd.com) is Senior Counsel in the EBRD's Office of the General Counsel. The contents of this publication reflect the opinions of individual authors and do not necessarily reflect the views of the EBRD. Terms and names used in this article to refer to geographical or other territories, political and economic groupings and units, do not constitute and should not be construed as constituting an express or implied position, endorsement, acceptance or expression of opinion by the EBRD or its members concerning the status of any country, territory, grouping and unit, or delimitation of its borders, or sovereignty. 
If Lehman Brothers had been a bit more Lehman Sisters ... we would not have had the degree of tragedy that we had as a result of what happened.

Gender diversity is closely linked with a number of important social issues, ranging from inclusion to equality. Recent studies have highlighted that gender diversity is not just a matter of discrimination but is also closely related to good corporate governance and to growth.

In a nutshell, corporate governance is the system by which companies are directed and controls are implemented. The key benchmark for good corporate governance are the OECD Principles of Corporate Governance (the Principles) —one of the 12 Key Standards for Sound Financial Systems. ${ }^{1}$ The Principles were first adopted in 1999 and later revised in 2004 and 2015.

Since the 1999 edition, the Principles have been emphasizing the need for independent and qualified boards, but considerations of gender diversity were only introduced in the 2015 revision. The 2015 G2o/OECD Principles of Corporate Governance now provide a timid but important non-binding reference to the importance of gender equality for policy-makers in building effective corporate governance processes.

The Principles recommend considering "voluntary targets, disclosure requirements, boardroom quotas, and private initiatives" to improve gender balance on boards and in senior roles. Furthermore, the oECD Guidelines on Corporate Governance of State-Owned Enterprises ${ }^{2}$ (soes) encourage "the ownership entity [to] consider the $O E C D$ Recommendation on Gender Equality

1 The Key Standards for Sound Financial Systems were highlighted in 1999 by the Financial Stability Forum (now known as the Financial Stability Board, an international body that monitors and makes recommendations about the global financial system) as vital for sound financial systems and deserving of priority implementation, depending on country circumstances. The Key Standards are broadly accepted as representing minimum requirements for good practice. See: <http://www.ebrd.com/what-we-do/sectors/ legal-reform/corporate-governance/international-standards.html > last accessed 15 January 2018.

2 The 2015 version of the OECD Guidelines on Corporate Governance of State-Owned Enterprises is available at: <http://www.oecd.org/corporate/guidelines-corporate-governance -SOEs.htm> last accessed 15 January 2018. 
in Education, Employment and Entrepreneurship."3,4 This Recommendation promotes a series of actions to improve gender diversity, including

encouraging measures such as voluntary targets, disclosure requirements and private initiatives that enhance gender diversity on boards and in senior management of listed companies; complementing such efforts with other measures to support effective board participation by women and expand the pool of qualified candidates; continuing to monitor and analyses the costs and benefits of different approaches_including voluntary targets, disclosure requirements or boardroom quotas - to promote gender diversity in leadership positions in private companies.

The Financial Crises Triggered a Different Vision of Board Diversity

In the aftermath of the 2008-2009 financial crisis, scholars ${ }^{5}$ started looking in depth at the board composition of various firms that had been negatively affected by the crisis. The growing awareness of both the under-representation of women in leadership and the evidence of their key contributions to business has led to increased efforts to improve gender balance in senior management, including in boards.

Governments, shareholders, investors and companies have started establishing measures to attempt to close the gender gap through boardroom quotas, regulatory reforms, disclosure, targets and other tools. In some cases, they have been successful, and in others, less so. According to a 10-year survey of Fortune Global 200 companies, published in 2015, the US has seen the number

3 The "Ownership Entity" is defined as the part of the state responsible for the ownership function, or the exercise of ownership rights in soes.

4 The 2013 OEcD Recommendation of the Council on Gender Equality in Education, Employment and Entrepreneurship is available at: <http://www.oecd.org/els/2013-oecd -recommendation-of-the-council-on-gender-equality-in-education-employment-and-entre preneurship-9789264279391-en.htm> last accessed 15 January 2018.

5 See among others: Joseph A McCahery and Erik PM Vermeulen, "Understanding the Board of Directors after the Financial Crisis," ECG I-Law Working Paper No. 229, Lex Research Topics in Corporate Law \& Economics Working Paper No. 2013-5, available at: <https://papers.ssrn .com/sol3/papers.cfm?abstract_id=\%202336614> last accessed 28 March 2018; and PJ Engelen, A van den Berg, G van der Laan, "Board Diversity as a Shield During the Financial Crisis," in: S Boubaker, B Nguyen, D Nguyen (eds), Corporate Governance (2012), Springer, Berlin, Heidelberg. 
of women on boards increase by less than one percent per year since 2004. ${ }^{6}$ However, Europe seems to be the region where the discussion of diversity has had the greatest impact, with an increase exceeding 12 percent in the period $2011-15 .^{7}$

The debate in Europe began officially in 2011, when the European Commission published a working paper on "The Gender Balance in Business Leadership." ${ }^{8}$ The paper points out that:

across Europe a typical board of ten has just one female member. In 97 percent of cases the board is chaired by a man. In 2010, women accounted for just below 12 per cent of board members in the largest publicly listed companies in the EU and for only just over 3 percent of board chairs.

The same paper also reflects on the situation in the US, where "women hold around 15 per cent of board seats in the Fortune 500 companies and chair 2 per cent of boards."

In November 2012, the European Commission proposed legislation that aimed to see women attain a 40 percent of the non-executive board-member roles in publicly listed companies, with the exception of small and mediumsized enterprises. ${ }^{9}$ The directive remains under discussion today and although there is a broad consensus in favor of measures to improve the gender balance on boards, some European Union countries believe that binding measures at the EU level are not the best way to pursue the objective. ${ }^{10}$

6 Source: “2015 CWDI Report: Women Board Directors in APEC Economies," by Corporate Women Directors International (2015), page 5, available at: <http://globewomen.org/ CWDInet/wp-content/uploads/2015/og/2015-CWDI-APEC-Women-Board-Directors-Re port.pdf $>$ last accessed 15 January 2018.

7 Source: "Gender Diversity on European Boards, Realizing Europe's Potential: Progress and Challenges," European Women on Boards (April 2016), available at: $<$ http://european .ewob-network.eu/wp-content/uploads/2016/o4/EWoB-quant-report-WEB-spreads.pdf> last accessed 15 January 2018.

8 The European Commission Working Paper is available at: <http://ec.europa.eu/justice/ gender-equality/files/gender_balance_decision_making/110301_gender_balance_busi ness_leadership_en.pdf> last accessed 15 January 2018.

9 The press release on the new EU legislative proposal is available at: $<\mathrm{http}: /$ europa.eu/ rapid/press-release_IP-12-1205_en.htm > last accessed 15 January 2018. The text of the Proposal for a Directive of the European Parliament and of the Council on improving the gender balance among non-executive directors of companies listed on stock exchanges and related measures is available at: <http://eur-lex.europa.eu/legal-content/EN/TXT/? qid=1441109473231\&uri=CELEX:52012PCo614 > last accessed 15 January 2018.

10 The national parliaments of Denmark, the Netherlands, Poland, Sweden, the United Kingdom and one of the two chambers of the parliament of the Czech Republic (the Chamber 
However, the discussion did not stall and in June 2013 another important piece of legislation was approved. The revised Capital Requirements Directive introduced a number of requirements to improve corporate governance of financial institutions in Europe. The Directive emphasizes that

the lack of monitoring by management bodies of management decisions is partly due to the phenomenon of 'groupthink.' This phenomenon is, inter alia, caused by a lack of diversity in the composition of management bodies. To facilitate independent opinions and critical challenge, management bodies of institutions should therefore be sufficiently diverse as regards age, gender, geographical provenance and educational and professional background to present a variety of views and experiences. Gender balance is of particular importance to ensure adequate representation of population. In particular, institutions not meeting a threshold for representation of the underrepresented gender should take appropriate action as a matter of priority.

\section{Why Gender Diversity on Boards Matter}

Good corporate governance standards require company boards to be diverse. This diversity ensures that a board is able to perform its oversight function effectively, and in particular to avoid "groupthink," which arises where directors all have similar backgrounds and experience and results in a lack of robust challenge in the decision-making process.

Diversity has been historically interpreted as an appropriate balance of skills, experience, independence and knowledge of the company's business. Since 2007, research has been showing the impact of gender diversity on corporate boards. For example, there is now evidence to support the hypothesis that greater female representation on boards improves companies' performance and has a positive impact on governance, reducing the likelihood of bribery, fraud and other governance scandals that may depress business confidence.

Among the many published studies, it is worth mentioning a 2013 research study by Professor Michel Ferrary at SKEMA Business School in France, who

of Deputies) submitted reasoned opinions within eight weeks of the submission of the Commission's proposal, alleging that it did not comply with the principle of subsidiarity. For further details, see: <http://www.europarl.europa.eu/legislative-train/theme-area-ofjustice-and-fundamental-rights/file-gender-balance-on-boards> last accessed 28 March 2018. 
concluded that companies with strong female representation on the management team perform better. ${ }^{11}$ In 2015, MSCI - an index provider-found that companies with more women on their boards had delivered a 36 percent better return on equity since 2010 than those groups lacking gender diversity. ${ }^{12}$ In another study, MSCI found that companies with a higher percentage of women on boards tended to have fewer instances of governance-related scandals such as bribery, corruption, fraud, and shareholder battles. Furthermore, companies with higher percentages of women on boards had higher environmental, social and governance (ESG) risk-management ratings and strategies across virtually all risk issues. ${ }^{13}$ In 2016, the Peterson Institute for International Economicsa think-tank-published an analysis of nearly 22,000 firms from 91 countries suggesting that the presence of women in corporate leadership may improve firm performance, with the largest gains depending on the proportion of female executives. ${ }^{14}$

The most recent studies confirm that the relationship between diversity and business performance persists in the longer term. In January 2018, McKinseya global management consulting firm—-published new research ${ }^{15}$ continuing

11 In particular, Professor Michel Ferrary's study suggests that companies where at least 35 percent of the management team are women performed better during financial crises. The study analyzes the stock performance of companies in the CAC40-the Parisian stock index-and created a separate index of 10 companies whose management teams consisted of 35 percent women (the so-called "Femina Index"). By comparing the CAC40 and the Femina Index from 2007 to 2012, Ferrary found that the CAC40 lost 34.70 percent of its value during the six years period, whereas companies in the Femina Index lost only 5.28 percent.

12 This conclusion is based on a 2015 MSCI study, available at: <https://www.msci.com/ documents/10199/04b6f646-d638-4878-9c61-4eb91748a82b> last accessed 15 January 2018, which looks at companies with a "strong female leadership." The study designates a company as having "strong female leadership" if the company's board has three or more women or if its percentage of women on the board is above the average for its country. A company is also considered to have "strong female leadership" if it has a female CEO and at least one woman on the board.

13 See: "2014 Survey of Women on Boards, Executive Summary," MSCI (November 2014). Available at: <https://www.msci.com/documents/10199/bo8aa5co-5304-4f6c-975f-83aoa $6414838>$ last accessed 15 January 2018.

14 See: Marcus Noland, Tyler Moran and Barbara Kotschwar, "Is Gender Diversity Profitable? Evidence from a Global Survey," Peterson Institute for International Economics (February 2016), available at: <https://piie.com/publications/wp/wp16-3.pdf> last accessed 15 January 2018.

15 See: Vivian Hunt, Sara Prince, Sundiatu Dixon-Fyle and Lareina Yee, "Delivering Through Diversity," McKinsey \& Company (January 2018). Available at: <https://www.mckinsey .com/business-functions/organization/our-insights/delivering-through-diversity> last accessed 25 January 2018. 
the work initiated in $2015^{16}$ but on a larger scale. The new research clearly shows that the statistically significant correlation between a more diverse leadership team and financial outperformance continues to hold true in an updated, enlarged and global dataset. In addition, the research highlights that there is a "penalty for opting out," as companies in the dataset showing the least gender and ethnic or cultural diversity were 29 percent less likely to achieve aboveaverage profitability than were all other companies.

\section{Gender-diverse Boards: Trends and Current Status}

Based on such supporting evidence on the correlation between gender diversity and company performance, one would expect that companies would have promptly started looking to increase the presence of women on their boards and in key management positions. Recent surveys show that the trend is moving in this direction, although not always at the expected pace. Some positive results have been achieved in Europe, but to a lesser degree in the US, where "Fewer large companies are run by women than by men named John,"17 and in Asia.

The average percentage of women on company boards in the 28 countries of the EU (see Chart 2.1) increased from 11.9 percent in 2010 to 25.3 percent in $2017{ }^{18}$ while in the US women's representation on corporate boards improved only from 12.7 percent in $2010^{19}$ to 14.2 percent in $2017 .{ }^{20}$

16 See: Vivian Hunt, Dennis Layton and Sara Prince, "Diversity Matters," McKinsey \& Company, (2 February 2015), available at: <https://www.mckinsey.com/ /media/mckinsey/ business\%2ofunctions/organization/our\%2oinsights/why\%2odiversity\%2omatters/ diversity\%2omatters.ashx> last accessed 25 January 2018.

17 See the New York Times article reporting that "Fewer large companies are run by women than by men named John, a sure indicator that the glass ceiling remains firmly in place in corporate America." The article is available at <https://www.nytimes.com/2015/03/o3/ upshot/fewer-women-run-big-companies-than-men-named-john.html?partner=rss\& emc $=$ rss\&abt $=0002 \& a b g=1 \& \_r=0>$ last accessed 15 January 2018.

18 Source: European Institute for Gender Equality <http://eige.europa.eu/gender-statistics/ dgs/about> accessed 26 January 2018. The same dataset shows that the EU 28 average of female executives moved from 10.4 percent in 2012 to 15.8 percent in 2017 (while the average for CEOS was 2.5 percent in 2012 and 5.5 percent in 2017).

19 Data from "The CS Gender 3000: The Reward for Change," Credit Suisse Research Institute, September 2016.

20 Data from "Women in the Boardroom: A Global Perspective," Fifth Edition, Deloitte (June 2017), available at: <https://www2.deloitte.com/uk/en/pages/risk/articles/women-in-the -boardroom5th-edition.html > last accessed ${ }_{15}$ January 2018. 

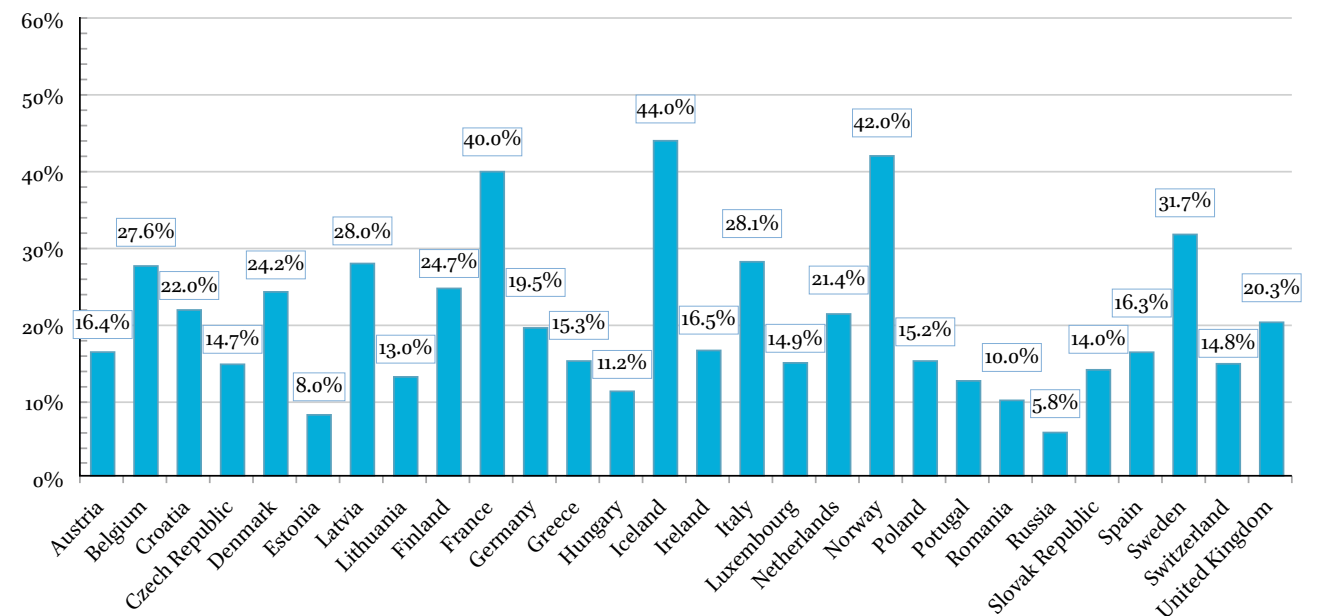

CHART 2.1 Percentage of board seats held by women in Europe, 2017 SOURCE: DATA FROM "WOMEN IN THE BOARDROOM: A GLOBAL PERSPECTIVE," FIFTH EDITION, DELOITTE (2017).

With regards to Asian economies, the situation is quite uneven (see Chart 2.2). In Japan and South Korea, the representation of women on boards barely reaches the 4 percent threshold. ${ }^{21}$ Meanwhile, in Indonesia, the level is below 10 percent. ${ }^{22}$ China, the largest economy in the region, has a relatively high female labor participation rate-74 percent of Chinese women work-but when it comes to their representation on boards, the average drops to less than 10 percent. ${ }^{23}$ Women's representation on boards in India, Malaysia, the Philippines, Singapore and Thailand is slightly over the 10 percent threshold. A study by the European Bank for Reconstruction and Development (EBRD), looking at the boards of the 10 largest companies in each of the economies where the Bank operates, ${ }^{24}$ shows that in Kazakhstan, the Kyrgyz Republic, Mongolia and Tajikistan, women's representation on boards is well below 10 percent. ${ }^{25}$

\section{$21 \quad$ Ibid.}

22 Ibid.

23 Source: "Women in Leadership in Asia Pacific," The Economist (19 September 2016), $<$ https://www.willistowerswatson.com/en/insights/2016/og/Women-in-leadership-in -Asia-Pacific $>$ last accessed 15 January 2018.

24 The EBRD is an international financial institution that operates in 38 economies across three continents. See <http://www.ebrd.com/where-we-are.html>. The 2016 E BRD Corporate Governance Sector Assessment is available at $<\mathrm{http}$ //www.ebrd.com/what-we -do/sectors/legal-reform/corporate-governance/sector-assessment.html>

25 Source: EBRD research. 


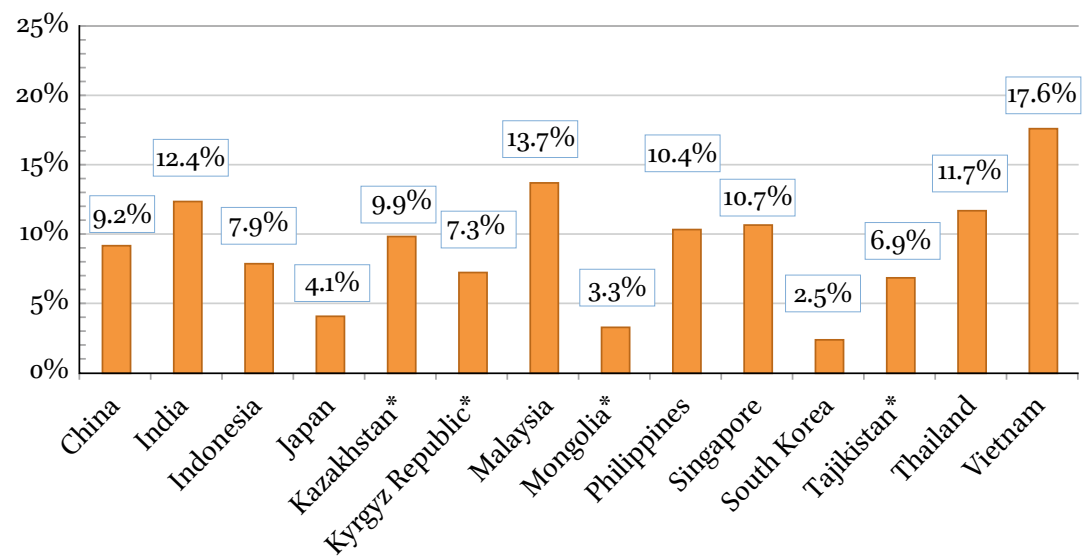

CHART 2.2 Percentage of board seats held by women in Asia, 2017 SOURCE: DATA FROM "WOMEN IN THE BOARDROOM: A GLOBAL PERSPECTIVE”, FifTH EDition, DELOITTE (2017). * DENOTES DATA FROM EBRD RESEARCH.

In recent years, a number of regulatory requirements have been introduced (from quotas to voluntary requirements in corporate governance codes) to improve gender diversity on boards.

Out of the 12 largest markets in Europe, five now have mandatory gender quotas for boards ${ }^{26}$ and the other seven either have an optional quota or a "comply-or-explain" recommendation in their corporate governance codes. ${ }^{27}$

In Norway, a gender quota of 40 percent of women on publicly listed company boards was introduced in $2003 .{ }^{28}$ It included a severe penalty of delisting for companies that did not comply within two years from July 2005, the date when the law entered into force. France, Iceland and Spain followed suit with targets of 40 percent-although with less severe penalties - and other countries also introduced quotas, albeit with lower thresholds. In Italy, a new

26 The five European countries that have mandatory quotas are Belgium, France, Germany, Italy and Norway.

27 The seven European countries that have either an optional quota or a comply-or-explain recommendation in the corporate governance codes are Denmark, Finland, the Netherlands, Spain, Sweden, Switzerland and the UK.

28 See: Lizette Alvarez, "Norway is Set to Compel Boardrooms to Let More Women In," New York Times (14 July 2003) <http://www.nytimes.com/2003/07/14/world/norway-is-set-to -compel-boardrooms-to-let-more-women-in.html> last accessed 15 January 2018. 
law requiring listed companies to ensure that there is a balance between genders on a board and that at least a third of the board is reserved for the under-represented gender-which is unlikely to be male-became effective in August 2011. ${ }^{29}$ In cases of non-compliance, СОNSOB-the Italian securities regulator-can issue severe fines of up to EUR1 million. So far, no companies have received sanctions. Nevertheless, the percentage of women on the boards of listed companies in Italy saw an increase of nearly 12 percent between 2012 and 2016. ${ }^{30} \mathrm{In} 2015$, Germany also imposed a quota, mandating that 30 percent of supervisory board seats be filled by women. ${ }^{31}$

A recent study ${ }^{32}$ has shown that the countries that have introduced mandatory quotas show higher growth of gender diversity on boards, ${ }^{33}$ compared with those that have only voluntary recommendations. In Europe, nowadays, there is a 32 percent difference between the average percentage of women on boards in Norway and the corresponding percentage in Romania, which has only a voluntary recommendation in the national corporate governance code. There are, however, exceptions — notably, the United Kingdom (UK), which is discussed below.

\section{$5 \quad$ Gender Quotas Incite Heated Debates}

In France, the introduction of the gender quota was a source of much debate, and even some women were against the idea. "No one wants to be a secondclass citizen," said one, explaining that she would not want to be on a board that was required by law to have a female member. ${ }^{34} \mathrm{~A}$ common misconception is

29 Law 120/2011 "Gender Balance on the Board of Listed Companies." The law amended the text of the Legislative Decree no. $5^{8}$ dated 24 February 1998, related to financial intermediation.

30 See: "Women in the Boardroom: A Global Perspective," Fifth Edition, Deloitte (June 2017).

$31 \quad$ Ibid.

32 See: K De Pril and M Roberts, "Gender Diversity on European Boards, Realizing Europe's Potential: Progress and Challenges," European Women on Boards (April 2016), <http:// european.ewob-network.eu/wp-content/uploads/2016/o4/EWoB-quant-report-WEB -spreads.pdf $>$ last accessed 15 January 2018.

33 The countries that showed higher growth in gender diversity on boards are Italy (which had the lowest starting point, with an average of 4.2 percent female board membership in 2011), Belgium and France. In Germany, the trend is not yet apparent because the quota was only recently introduced. Source: "Women in the Boardroom: A Global Perspective," Fifth Edition, Deloitte (June 2017).

34 The citation is taken from Margaretha Wiersema and Marie Louise Mors, "What Board Directors Really Think of Gender Quotas," Harvard Business Review (14 November 2016), 
that gender quotas lead to the selection of unqualified women or to selection based purely on gender, rather than qualifications.

Recent research, however, seems to demonstrate otherwise.

A study by Harvard University ${ }^{35}$ found that the imposition of quotas has resulted not only in greater gender diversity, but also in a more professional and formal approach to the selection of board members. In Norway, for instance, after the introduction of gender quotas, the entire process of recruiting board directors became more rigorous and professional. The nomination requirements were clarified, the responsibility of the board nomination committee was acknowledged and the focus on the composition of boards was improved. ${ }^{36}$

"I am not a great supporter of quotas but in this case it's making difference," the CEO of one of Europe's largest executive search firms said in an interview on gender quotas in Norway. "It has changed the conversation. It clearly has been put on the agenda of companies." 37

Not all countries have reached a political consensus on mandatory quotas. The US is among the few developed Western economies that have neither voluntary nor mandatory targets. Some US states, such as California, Massachusetts, Illinois and Pennsylvania, have started passing non-binding measures, but given the latest data on the gender diversity in US boards-showing that the representation of women on the boards of S\&P 500 companies has not increased significantly over the past decade-there is increasing recognition that without a more formal effort the situation is unlikely to change.

In Asia, only India and Malaysia have introduced mandatory gender quotas. In India, the 2013 Companies Act requires all listed companies to have at least one woman on their board. As a result, the number of women on boards has increased by 4.7 percent over the past two years, from 7.7 percent to 12.4 percent. $^{38}$ In Malaysia, in 2011, the government approved a policy requiring companies with more than 250 employees to have 30 percent of senior management positions filled by women by $2016 .{ }^{39}$ The target was missed and the

\footnotetext{
<https://hbr.org/2016/11/what-board-directors-really-think-of-gender-quotas> last accessed 15 January 2018.

35 Ibid.

36 Ibid.

37 See: Oliver Staley, "You know those quotas for female board members in Europe? They're working," Quartz (3 May 2016), <https://qz.com/674276/you-know-those-quotas-for-female-board-members-in-europe-theyre-working/> last accessed 15 January 2018.

38 See: "Women in the Boardroom: A Global Perspective," Fifth Edition, Deloitte (June 2017).

39 Source: Meijun Qian, "Women's Leadership and Corporate Performance," AD в Economics Working Paper Series, No. 472 (January 2016), <https://www.adb.org/sites/default/files/ publication/179587/ewp-472.pdf> last accessed 15 January 2018.
} 
deadline extended to 2020, with the Prime Minister threatening to "name and shame" companies with no women on their boards by 2018.40

Other countries have established gender diversity targets, but so far tangible results have been limited. For instance, in Japan, the government set a target in 2003 of 30 percent of women in corporate management positions by 2020 , with the Prime Minister encouraging companies to take voluntary steps towards appointing at least one female board member by 2013. In the same year, the Tokyo Stock Exchange required companies to disclose their female board representation. Furthermore, the 2015 Corporate Governance Code included a specific clause on gender diversity. As a result, the percentage of all-male boards decreased from 79 percent in 2012 to 65 percent in 2016, but-as Chart 2.2 illustrates - women's representation on boards remains very limited.

\section{Are Voluntary Recommendations in National Corporate Governance Codes the Solution?}

The effectiveness of corporate governance codes depends on a robust and supportive institutional environment, where companies, investors and regulators all play a role. Codes are a starting point and not an end in themselves. A simple introduction of a specific provision in the code is not, in and of itself, capable of producing tangible results. In particular, corporate governance codes-especially those that are to be implemented under the socalled "comply-or-explain" mechanism ${ }^{41}$ —are intended to make companies disclose the practices they have in place and to provide explanations in cases where these are not aligned with the code's recommendations. It is then up to the market - in particular, investors - to consider if these practices are sound enough or should trigger some reactions.

The problem is that in many countries markets are shallow, liquidity and corporate governance culture are limited, and trading does not seem to be driven by corporate governance considerations, such as the issuers' compliance-or

40 Source: Hwok-Aun Lee, "Malaysia's push for gender equality holds lessons for Asia," Nikkei Asian Review, (22 August 2017), <https://asia.nikkei.com/Politics/Malaysia-s-push-for -gender-equality-holds-lessons-for-Asia> last accessed ${ }_{15}$ January 2018.

41 The "comply-or-explain" approach means that companies should comply with the code, but they can get away with not doing so if they are able to explain their actions convincingly to shareholders. This approach was first conceived in the UK in 1992. In 2006, it was institutionalized in the European Union with the adoption of Directive 2006/46/EC and then reconfirmed by Directive 2013/34/EU, which requires companies "whose transferable securities are admitted to trading on a regulated market" in the EU to "include a corporate governance statement in their management report." 
lack of compliance-with the recommendations of the national corporate governance code. In 2010, the European Commission issued a Green Paper on Corporate Governance in Financial Institutions ${ }^{42}$ noting that the "shareholders' lack of interest in corporate governance raises questions in general about the effectiveness of corporate governance rules based on the presumption of effective control by shareholders for all listed companies."

Recently, the EBRD completed an assessment of corporate governance in 34 economies in its region. ${ }^{43}$ In all economies assessed, a corporate governance code is in place, but in most cases there is no clear evidence of their implementation in practice. In addition, only in four countries ${ }^{44}$ do the codes recommend that companies take gender into consideration when appointing board directors. There are no specific requirements to have a certain level of gender representation on a board. In fact, none of the countries that have a specific gender reference in their code outmatches its peers in female representation on boards.

This situation is not limited to the economies where the EBRD operates and only in a few countries are codes making a difference.

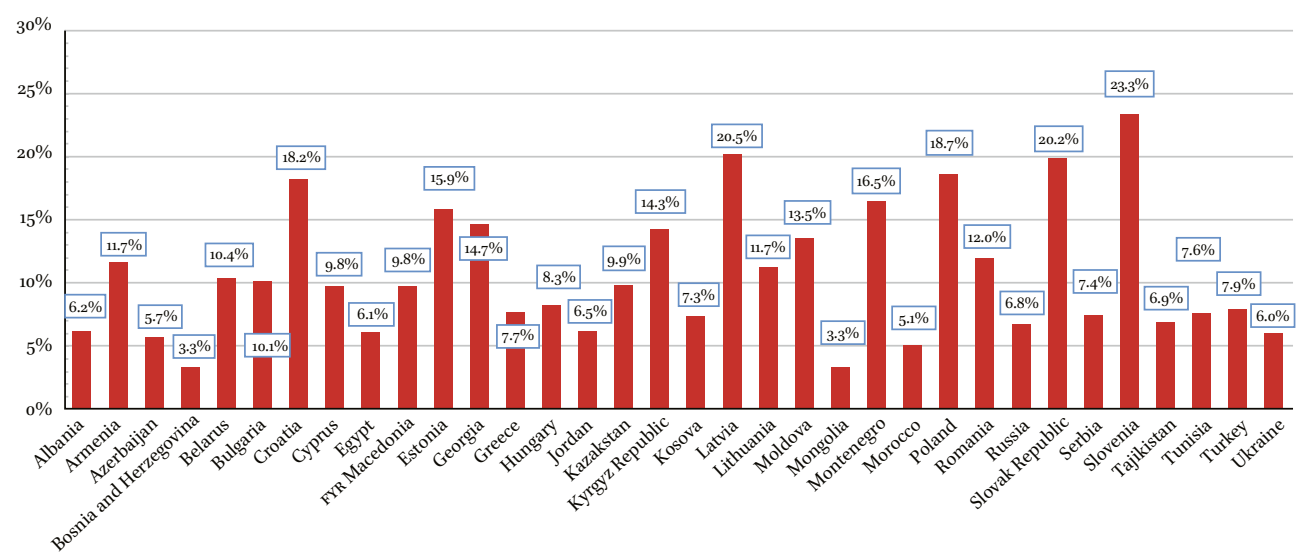

CHART 2.3 Average female presence on boards of the 10 largest (listed) companies in the EBRD region

SOURCE: EBRD RESEARCH, BASED ON INFORMATION PUBLISHED ON THE WEBSITES AND ANNUAL REPORTS OF THE 10 LARGEST (LISTED) COMPANIES IN 2015.

42 Green Paper: "Corporate governance in financial institutions and remuneration policies" $\{\operatorname{COM}(2010) 285$ final $\}\{\operatorname{COM}(2010) 286$ final $\}\{\operatorname{SEC}(2010) 669\},<$ http://eur-lex.europa.eu/ legal-content/EN/TXT/?uri=celex:52010DCo284> last accessed 15 January 2018.

43 See footnote 24.

44 These countries are Albania, FYr Macedonia (limited to the requirement to discloseamong others - the gender of members of management and supervisory boards), Greece, Poland and Romania. 
In the UK, for instance, the code implementation is carefully assessed by investors and monitored by the Financial Reporting Council—the "owner of the code" - which produces annual monitoring reports ${ }^{45}$ and places great emphasis on the enhancement of a corporate culture that can deliver sustainable good performance. ${ }^{46}$ Furthermore, in addition to the code recommendations, the UK government — backing the Davies Review ${ }^{47}$ — set a non-binding target of 25 percent women on the boards of the FTSE 100 companies by the end of 2015, which was achieved and then raised to 33 percent by 2020. In the UK there is no mandatory quota by law. However, the positive change was the result of a combined effort by many parties, including the government, specific recommendations in the code, the media, a change in the culture of companies, ${ }^{48}$ and, last but not least, investors.

The attitude of investors and their engagement with companies for better corporate governance has grown over time, based on the understanding that good corporate governance adds value. The process has also been promoted by the active role of the UK regulator, which has recently moved to name and shame those investors that, albeit having endorsed the UK Stewardship Code, ${ }^{49}$

45 In the UK, the Financial Reporting Council has also established an active dialogue with investors, through the Stewardship Code, requiring it-among others-to engage with listed companies for a better implementation of the UK Corporate Governance Code.

46 See: <https://www.frc.org.uk/directors/the-culture-project> last accessed 15 January 2018.

47 The Davies Review is a government-backed commission chaired by Lord Davies, which was first introduced in 2010 to examine the under-representation of women on boards of UK listed companies. In 2011, Lord Davies released a "Women on Boards" report which aimed to raise the profile of gender equality and promote the cause among UK companies. In the report, Lord Davies set the voluntary target of 25 percent representation by women on the boards of FTSE 100 companies by the end of 2015. The target of 25 percent was met and in October 2015 Lord Davies released his five-year summary of the report, raising the target to 33 percent by 2020 on FTSE 350 boards. The Lord Davies Review, "Women on Boards" (February 2011) is available at: <https://www.gov.uk/government/ uploads/system/uploads/attachment_data/file/31480/11-745-women-on-boards.pdf> last accessed 15 January 2018. The Review undertaken in 2015 is available at: <https:// www.gov.uk/government/uploads/system/uploads/attachment_data/file/482059/BIS -15-585-women-on-boards-davies-review-5-year-summary-october-2015.pdf> last accessed 15 January 2018.

48 In this regard, it is worth noting the " $30 \%$ Club," a global campaign that signs up board chairs and CEOs to prioritize action to create a better balance of men and women at all levels of their organizations rather than treating the matter as a "women's issue." See more at: $<$ https://3opercentclub.org/> last accessed 15 January 2018.

49 The UK Stewardship Code aims to enhance the quality of engagement between investors and companies. The Stewardship Code consists of seven Principles. Principle 3 is about "monitoring their investee companies" with a clear focus on corporate governance. About 300 asset managers, asset owners and service providers have signed up to the Stewardship Code. Signatories are encouraged to publish a statement on their website showing the extent to which they have complied with the Code ("comply or explain"), to notify the 
do not dedicate enough effort to "engaging" 50 with companies for better compliance with the corporate governance code..$^{51}$

As a result, investors are now playing a key role in triggering the change. For example, Legal \& General Investment Management (LGIM), the London-based fund company that oversees USD1 trillion of assets, recently toughened its voting stance after deciding that simply urging companies to take action on board diversity has not delivered results. LGIM began pushing for better board diversity in the US eight years ago and has committed to voting against nomination committee chairs at any company in the S\&P 500 index that still has an allmale board from 2017 onwards. LGIM decided to vote against all-male boards at Britain's largest companies in 2015, and extended that policy to include FTSE 250 companies in 2016. ${ }^{52}$ Aviva Investors, the London-headquartered asset manager, also decided to vote against all-male boardrooms in the UK in 2014. ${ }^{53}$

Financial Reporting Council (FRC) when they have done so and whenever the statement is updated. The UK Stewardship Code is available at: <https://www.frc.org.uk/investors/ uk-stewardship-code > last accessed 15 January 2018.

5o The UK Stewardship Code makes clear that "For investors, stewardship is more than just voting. Activities may include monitoring and engaging with companies on matters such as strategy, performance, risk, capital structure, and corporate governance, including culture and remuneration. Engagement is purposeful dialogue with companies on these matters as well as on issues that are the immediate subject of votes at general meetings." (Guidance to Principle 1).

$5^{1}$ In the UK, the FRC is the "owner" of the UK Corporate Governance Code and the UK Stewardship Code. The FRC publishes an annual monitoring report on the level of company compliance with the code. The Council realized that in some cases, the signing of the Stewardship Code was merely a declaration, with no material action undertaken. Hence, the FRC started reviewing the quality of compliance statements and began to "name and shame" or "name and shine" asset managers, asset owners and service providers, by grouping them into tiers based on the quality of their Code statements. See: <https:// www.frc.org.uk/investors/uk-stewardship-code/uk-stewardship-code-statements> last accessed 15 January 2018.

52 "Corporate Governance and Responsible Investment Policy-UK 2016" LGIM states at page 6: "Voting on structure and operation of boards. LGIM will usually support the board's recommendations and nominees for election to the board. However, if the company does not provide a satisfactory explanation then LGIM will oppose (...) the chairman of the board and/or the chairman of the nominations committee, of a FTSE100 company where there is not a minimum of $25 \%$ women at board level; the chairman of FTSE 250 companies, where there is not a minimum of $20 \%$ women at board level. We will use our discretion when considering voting against the chairman of the board, also taking into account the percentage of female representation below board level and the disclosures relating to diversity; the (re)election of the chairman or the chairman of the nomination committee if the board has failed to address the issue of diversity through the disclosure of policies, the implementation of measurable targets, or actual board change consistent with company strategy."

53 "UK Corporate Governance and Corporate Responsibility Voting Policy," Aviva Investors (2016), states at page 3: "3.2. Gender diversity. (...) We are unlikely to support the 
Several of the world's largest fund companies, including BlackRock, Vanguard, Fidelity and Aberdeen, are also pressing for greater gender diversity on boards, but have not yet committed to voting against directors at companies with allmale boards. ${ }^{54}$

These initiatives are not limited to the UK or the private sector: Rhode Island Pension Fund - the pension fund administered by the US state of Rhode Island-has now committed to voting against any slate of directors nominated by the company that would result in women (or racial minorities) accounting for less than 30 percent of board seats. ${ }^{55}$

Outside major developed markets, the development finance institutions are among the largest investors. Since 1991, the EBRD has invested over EUR119 billion in more than 5,000 projects across private and public sectors in the economies where it invests. ${ }^{56}$ The EBRD is one of the signatories to the development finance institutions' (DFI's) Corporate Governance Initiative, ${ }^{57}$ which focuses on the improvement of corporate governance at investee companies of the respective DFIs. This Initiative, which has gathered more than 30 development finance institutions worldwide-representing a total of almost USD1 trillion in assets-has however not yet resulted in clear and concrete efforts to promote gender diversity on the boards of investee companies.

Most of the major DFIs, including the EBRD, have gender diversity policies governing their operations. The EBRD Strategy for the Promotion of Gender Equality $2016-2020^{58}$ was adopted in 2016 and commits to supporting

resolution to adopt the Report \& Accounts and/or the re-election of the Chairman of the Nomination Committee if we consider that the Board has not sufficiently addressed gender diversity and the reasons have not been adequately explained in the Report \& Accounts."

54 See: Madison Marriage, "All-male boards in the US face investor backlash," Financial Times (16 April 2017), <https://www.ft.com/content/2b915d48-1f81-11e7-a454-abo4428977fg> last accessed 15 January 2018.

55 See: "Women in the Boardroom: A Global Perspective," Fifth Edition, Deloitte (June 2017). The 2016 Annual Report of the Rhode Island Pension Fund is available at: $<\mathrm{https} / /$ dook ${ }_{7}$ k7mywg 42z.cloudfront.net/assets/58b967d6d4c96156fdo2odfi/2016_Annual_Report _RI_Treasury.pdf> last accessed 25 January 2018. It states on page 15 that "Rhode Island Treasury voted against more than 220 corporate board candidates at companies including Amazon, Delta Air Lines, and Intel, because their boards were severely lacking in gender or racial/ethnic diversity."

56 Source: EBRD, unaudited data as of 31 December 2017.

57 In September 2011, 30 development financial institutions signed a corporate governance statement, which is available at: <http://cgdevelopmentframework.com/> last accessed 15 January 2018.

$5^{8}$ The EBRD Strategy for the Promotion of Gender Equality 2016-2020 is available at: $<$ http://www.ebrd.com/documents/gender/ebrd-strategy-for-the-promotion-of-gender -equality.pdf> last accessed 15 January 2018. 
companies that express an interest in addressing gender equality by increasing the presence of women among non-executive directors on boards and in senior management. ${ }^{59}$ IFC - a member of the World Bank Group and the largest development financial institution focusing exclusively on the private sector in developing countries - has set a target of 30 percent female representation for IFC-nominated director positions. ${ }^{60}$

However, even if most DFIs have adopted a gender policy, the board composition of the institutions themselves suggests that they are not necessarily leading by example.

Among the 12 major treaty-based international financial institutions, only the Nordic Investment Bank shows a 50:50 gender-balanced board, while currently the Asian Infrastructure Investment Bank and the Eurasian Development Bank have no women serving on their boards. The EBRD is not faring well, either: less than 10 percent of its directors are women.

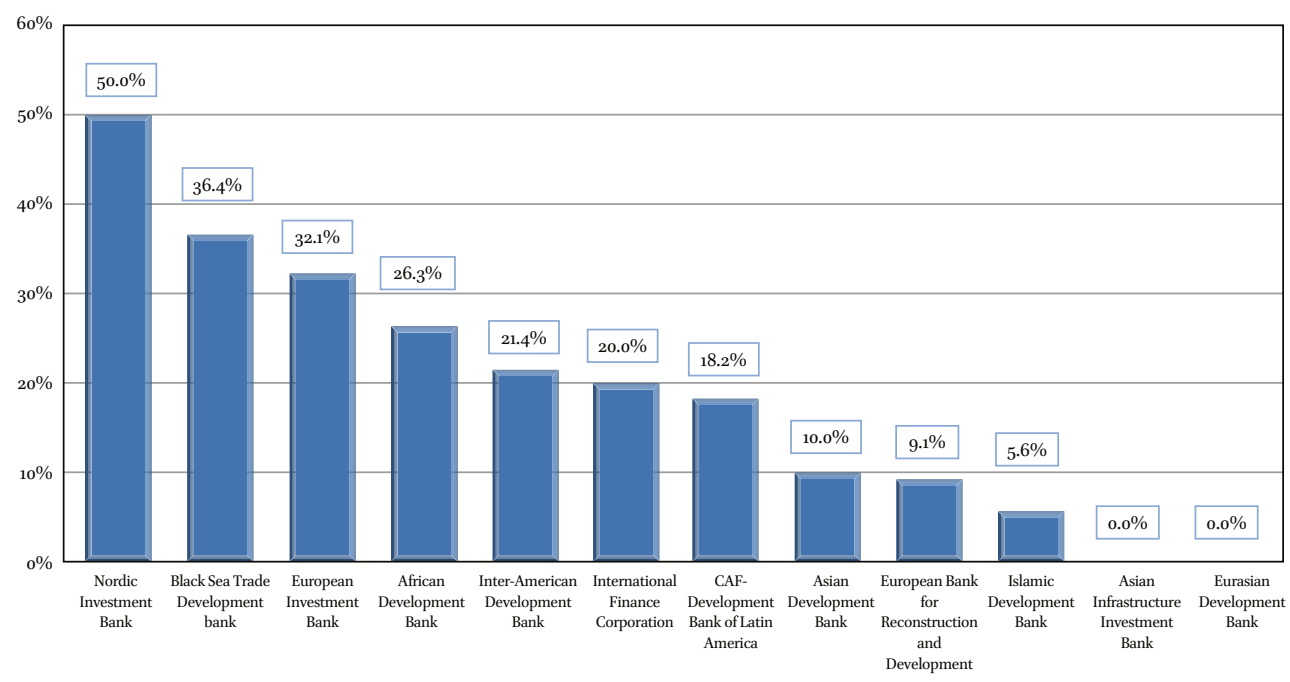

CHART 2.4 Percentage of women on the boards of 12 major international financial institutions

NOTE: BASED ON THE BOARD COMPOSITION (DIRECTORS ONLY-ALTERNATE DIRECTORS WERE NOT CONSIDERED) PUBLISHED ON THE WEBSITES OF THESE INSTITUTIONS. DATA ACCESSED ON 25 JANUARY 2018.

59 "Women in the Boardroom: A Global Perspective," Fifth Edition, Deloitte (June 2017).

60 See the IFC Corporate Governance, Women on Board webpage at: <http://www.ifc .org/wps/wcm/connect/topics_ext_content/ifc_external_corporate_site/ifc+cg/topics/ women+on+boards $>$ last accessed 15 January 2018. 
Moreover, none of these institutions seems to have gone the extra mile yet — as LGIM, Aviva or the Rhode Island Pension Fund have done-and taken a strong stance against all-male boards in its investee companies. This might be the next important step, but it needs to be implemented in a coordinated fashion, as changes cannot be achieved by one action or one player alone.

\section{$7 \quad$ A Lot Has Been Done, But Efforts Should Continue}

When discussing the importance of gender diversity on the boards of companies in developing markets, it seems there is still a lot of misunderstanding and a lack of knowledge about this important issue. In particular, it appears that the issue is still largely understood to be a social matter, not an issue of governance or one that affects economic growth.

Priorities for reform should include the continuation of work with governments to make a stronger business case for gender diversity on boards. This should entail capacity-building and corporate governance training, with targeted media communication explaining the value of board diversity as a governance issue and a driver of company performance.

The media, in particular, are a powerful means of creating the necessary culture that can trigger changes. The role of the media in improving corporate governance culture and behaviour has been largely demonstrated ${ }^{61}$ and we believe that the results achieved in the UK are also due to media exposure highlighting the importance of the issue and the need for reform. The media are important in shaping corporate policy and should not be ignored in any analysis of a country's corporate governance system. "People who actively resist diversity probably don't have all the information." 62

Companies should also be encouraged to disclose their board compositions on their websites and in their annual reports, thus allowing investors and other stakeholders to assess the situation and trigger further action. Examples in the

61 See among others: Baixiao Liu and John J. McConnell, "The role of the media in corporate governance: Do the media influence managers' capital allocation decisions?," Journal of Financial Economics, Volume 110, Issue 1, (October 2013), pages 1-17; and Alexander Dyck and Luigi Zingales, "The Corporate Governance Role of the Media," N BER Working Paper No. 9309 (November 2002).

62 Quote from Julie McKay, PwC Chief Diversity and Inclusion Officer. In The Guardian, 10 October $2016<$ https://www.theguardian.com/sustainable-business/2016/oct/10/gender -diversity-at-work-using-education-to-tackle-the-backlash> last accessed 25 January 2018. 
UK and France, where companies that do not adhere to the code are named and shamed by the regulators ${ }^{63}$ and the media have been largely successful as catalysts for change.

Most importantly, there is a need to start creating a culture among investors that promotes gender diversity and a common approach to exerting more pressure on their investees. DFIs-especially those that have endorsed the mission to improve corporate governance in their investee companies-have an important role to play in this regard by imposing higher governance standards on their investee companies, including requiring them to improve their board nomination processes and ensuring that nomination is based on qualifications and diversity requirements. There should be more robust challenge at general shareholders' meetings, in particular with regard to the appointment of board and board committee members. There should also be stronger efforts to convince boards and controlling shareholders to cast a wider net in their search for talented directors, beyond their usual comfort zone, while also promoting mechanisms ${ }^{64}$ that allow minority representation at the board. The Italian "voto di lista" mechanism ${ }^{65}$ might be a good example to follow, if supported by the necessary engagement from investors. These measures should be supported by training and education, particularly for women, to ensure that there is an increased pool of qualified women who can take up director roles.

63 The most recent report by the French Autorité des Marchés Financiers on corporate governance, executive compensation, internal control and risk management was published on 22 November 2017 and is available in French at: <http://www.amf-france.org/Publi cations/Rapports-etudes-et-analyses/Gouvernement-d-entreprise?docId=workspace \% ${ }_{3} \mathrm{~A} \% 2 \mathrm{~F} \% 2 \mathrm{FSpacesStore} \% 2 \mathrm{Fo3140cfe}-4026-49 \mathrm{f} 8$-a66e-131bob8eodaf\&langSwitch=true> last accessed 25 January 2018. The most recent full report available in English is the 2015 Report by the AMF on Corporate Governance and Executive Remuneration, available at: $<$ http://www.amf-france.org/en_US/Publications/Rapports-etudes-et-analyses/Societes -cotees-et-operations-financieres.html?docId=workspace $\%{ }_{3} \mathrm{~A} \% 2 \mathrm{~F} \% 2 \mathrm{FSpacesStore} \%$ 2Fca4oeea2-aoo1-4733-8829-251472fff $252>$ last accessed 25 January 2018. On the UK approach, please see footnotes 45 and onward, above.

64 For instance, cumulative voting, which is the procedure of voting for company directors whereby each shareholder is entitled to one vote per share, multiplied by the number of directors that are to be elected. This is advantageous for minority shareholders, because they can apply all of their votes to one candidate, thus making the appointment of that person more likely.

65 The "voto di lista" mechanism is compulsory for Italian listed companies. It calls for shareholders to vote on slates of nominees, submitted by controlling shareholders and minorities alike. A mechanism of this kind aims to ensure minority representation on corporate boards, providing that at least one director is elected from the slate submitted by minority shareholders. 